\title{
Assessment of Knowledge, Attitude, and Practice of Adverse Drug Reaction Reporting Among Community Pharmacy in Gondar Town, Ethiopia, 2021
}

Libsuye Yalgaw Zimamu ( $\sim$ libsuye@gmail.com )

DebreTabor Health Science College

Muluken Chanie Agimas

DebreTabor Health Science College

Gashaw Mehiret Wubet

DebreTabor University

\section{Research Article}

Keywords: Keyword: Knowledge, Attitude, Practice, Community, Pharmacist, Gondar, Ethiopia

Posted Date: December 21st, 2021

DOI: https://doi.org/10.21203/rs.3.rs-1188341/v1

License: (c) (i) This work is licensed under a Creative Commons Attribution 4.0 International License.

Read Full License 


\section{ASSESSMENT OF KNOWLEDGE, ATTITUDE, AND PRACTICE OF ADVERSE \\ DRUG REACTION REPORTING AMONG COMMUNITY PHARMACY IN \\ GONDAR TOWN, ETHIOPIA, 2021}

\section{Libsuye Yalgaw Zimamu (BSc)*1}

${ }^{1}$ Department of Health Informatics, Debre tabor Health Science College, Debre Tabor, Ethiopia;

Email: libsuye@gmail.com

${ }^{1}$ Muluken Chanie Agimas (MPH-Epidemiology)

${ }^{1}$ Department of Epidemiology, Debre tabor Health Science College, Debre Tabor, Ethiopia;

Email: mulukensrc12@gmail.com

Gashaw Mehiret Wubet (MD) ${ }^{2}$

${ }^{2}$ Debre tabor University, College of Health Science, Department of medicine, Debre tabor Ethiopia.

Email: mehiretg21stdr@gmail.com

*Corresponding author: Libsuye Yalgaw Zimamu (BSc)*1 Department of Health Informatics, Debre tabor Health Science College, Debre Tabor, Ethiopia.

Email libsuye@gmail.com

Phone $\mathbf{+ 2 5 1 9 3 2 8 5 9 9 7 5}$

\section{Authors:}

LYZ (libsuye@gamil.com)

MCA (mulukensrc12@gmail.com)

GMW (mehiretg21stdr@gmail.com) 


\section{ABSTRACT}

Background: Drugs can treat diseases, reduce symptoms, and enhance patients' health and quality of life. However, taking a drug is not always as easy as just swallowing a pill. This is because drugs have some unwanted effects. Adverse Drug Reactions (ADRs) are one of the leading causes of morbidity and mortality and contribute to excessive health care costs.

Objectives: To assess knowledge, attitude, and practice of health care providers on adverse drug reporting among community pharmacists, Gondar, Ethiopia

Methods: Community-based cross-sectional study designs were used from July - August 2021. The sampling method was a survey from community pharmacists. Self-administered questioner was used, and the collected data was entered into Epi-info Version 7.0 and exported to SPSS version 20 software for analysis.

Result: The study included 215 community pharmacy professionals to assess the knowledge, attitudes, and practices of adverse drug reaction reporting. From a total of 215 community pharmacy professionals, $34(15.8 \%)$ of the respondents were able to differentiate ADR from side effects and only 56(26\%) respondents felt that they are adequately trained in ADR reporting. Out of 215 respondents, 78(36.3\%) and 146(67.9\%) knew the availability of the national reporting system and ADR reporting form in Ethiopia respectively. The study revealed that 21.4\% [95\% CI: 18.6-35.9] and 42.3\% [95\% CI: 38.2-65.9] of community pharmacists have poor knowledge and negative attitude towards ADR reporting respectively.

Conclusion: Underreporting of ADR by community pharmacists was identified in this study. Training sessions to clarify the role of various community pharmacists in ADR reporting will hopefully fill the observed gap in knowledge and practices. The community pharmacy should formulate strategies to enhance the detection and reporting of ADRs.

Keyword: Knowledge, Attitude, Practice, Community, Pharmacist, Gondar, Ethiopia 


\section{INTRODUCTION}

\section{Background of the study}

Drugs can treat diseases, reduce symptoms, and enhance patients' health and quality of life. However, taking a drug is not always as easy as just swallowing a pill. This is because drugs have some side effects. With the use of any drug comes the possibility of unintended consequences which when harmful are referred to as adverse drug reactions(1). World Health Organization defines Adverse Drug Reaction (ADR) as "any noxious, unintended, and undesired effect of a drug, which occurs to normal doses used in humans for prophylaxis, diagnosis, or therapy" (2). Adverse drug reactions (ADRs) are the most common cause of morbidity, mortality, and poor therapeutic outcomes (3).

ADR is any noxious, unintended, and undesired effect of the drug that occurs as a result of treatment with a drug at normal doses used in man for diagnosis, prophylaxis, and treatment $(1,4)$. ADRs can be described as "an appreciably harmful or unpleasant reaction, resulting from an intervention related to the use of a medicinal product, which predicts hazard from future administration and warrants prevention or specific treatment, or alteration of the dosage regimen, or withdrawal of the product (5)

Generally, drugs and any other substances that are capable of producing a therapeutic effect can also lead to unwanted or adverse effects, some drugs produce low risk, the term "adverse effect" is preferable to other terms such as "side effect" or "toxic effect", side effect occurs via a different mechanism and may be dose-related or not $(2,3)$. A toxic effect is an exaggeration of the desired therapeutic effect which is usually not common at normal doses, and drug toxicity occurs at a higher dose that is to say the toxic effect is always dose-related $(3,4)$ The terms "adverse reaction" and "adverse effect" are interchangeable, except that an adverse effect is seen from the point of view of the drug, whereas an adverse reaction is seen from the point of view of the patient 


\section{Methods and Materials}

\section{Study area and period}

This study was conducted among community pharmacies in Gondar town, North Ethiopia. Gondar town is located $732 \mathrm{~km}$ away from Addis Ababa (capital city of Ethiopia) and $160 \mathrm{~km}$ from Bahirdar (capital city of Amhara regional government).

Gondar is north of Tana Lake on the Lesser Angereb River and southwest of the Simien Mountains and is located 2133 meters above sea level. As of 2016, Gondar has a population of 299,969 having $12 \mathrm{sub}$ cites which consisted of 21 kebeles. There are around 79 community pharmacies.

\section{Study design}

$>$ Community-based cross-sectional study was used.

\section{Population}

\section{Source population}

$>$ All community pharmacists who was work in Gondar town were the source population.

\section{Study Population}

All community pharmacists who gave their informed consent constituted the study population.

\section{Inclusion and Exclusion criteria}

\section{Inclusion Criteria}

All community pharmacy or pharmacist who was work in Gondar town was included in this study

\section{Exclusion Criteria}

$>$ Pharmacy personnel are not willing to participate in the study or are on leave during the study.

\section{Study variables}

\section{Dependent}

$>$ Knowledge about ADR reporting

$>$ Attitude towards ADR reporting

$>$ The practice of ADR reporting

\section{Independent}

- Demographic factors (age, sex)

- The difference in the level of qualification
- Years of service

- On job training on ADR

- Patient load 


\section{Operational Definitions}

Adverse drug reactions: This is any noxious, unintended, and undesired effect of a drug, which occurs at doses used in humans for prophylaxis, diagnosis, or therapy.

Community pharmacies: Drug retail outlets led by pharmacy professionals

Pharmacy personnel: degree or diploma holder pharmacy professional working as a dispenser at community pharmacies of Gondar, Ethiopia.

Knowledge: Means theoretical or practical understanding of the subject matter(7).

$>75-100 \%$ of maximum score - Good Knowledge

$><75 \%$ of the maximum score - Poor knowledge.

Attitude: A predisposition or a tendency to respond positively or negatively towards a certain idea, object, person, or situation.

$>$ There are 10 items in the attitude part and each item had a maximum score of five liker scale making the maximum attitude score for the ten items 50. participants whose attitude scores were greater than and equal to $75 \%$ were categorized as having a positive attitude and those who scored below $75 \%$ were categorized as having a negative attitude towards ADR reporting(7).

Practice: Application of knowledge or practical approach to the subject matter.

From practice items the average of items. participants whose practice scores were greater than and equal to $50 \%$ were categorized as having a positive attitude and those who scored below $50 \%$ were categorized as having negative practice towards ADR reporting(7).

\section{Sample size determination and Sampling Technique}

The sample size of the study is the total population of dispensaries who are working in Gondar town community pharmacy and the sampling technique was the total survey.

\section{Data Collection Tool and Procedures}

An English version self-administered questionnaire was adapted from different kinds of literature used to collect data on all the specific objectives of the study most community pharmacists to be understood $(4,7)$. It contains different parts use to assess the following: socio-demographic characteristics among Gondar town community pharmacist professionals about knowledge, attitude, and practice adverse effects. Three Diploma Pharmacy Technician for data collection and one (clinical pharmacy) for supervision was assigned. The principal investigator was provided a one-hour orientation about the purpose and process of data collection for a single diploma pharmacy data collector. 
The data was collected on the day we assume to be a favorable time to get the respondents in their drug store. All community pharmacists were approached and only willing pharmacy personnel was filling the self-administered questionnaire. Instructions were first given by the data collector on the topic as well as the objective of the research. The community pharmacists were instructed not to consult or share information with their friends. The questionnaire was distributed by the data collector and collected back once the community pharmacists have filled in the required information.

\section{Data Quality Control}

The quality of data was ensured by doing the questioner pre-tested at Bahir dar town that is assumed to have similar characteristics to the targeted population. Based on their feedback the necessary amendment is done and the questioner is assessed for its clarity; the completeness and evaluate the validity and content of the questionnaire and modified accordingly. Close supervision is also made during the data collection and appropriate feedback is provided.

\section{Data Processing and Analysis}

Primarily the data is checked for its completeness, consistency, and validity. After checking the collected data, then the data was entered to EPI-info version 7.0 and transferred to SPSS version 20 statistical software for analysis. Data will be cleaned and coded for completeness, consistency and to minimize errors. SPSS version 20 statistical software is used and frequencies and odds ratio were determined. Descriptive analyzed statistical results were presented by texts, graphs, diagrams, and tables, but the analytic form of findings was presented by text form of odds ratio and Multivariable

binary logistic regression model was fitted and adjusted odds ratios with $95 \%$ confidence interval were computed to determine the strength of association between each variable with KAP of community pharmacists on ADR. Variables with P-value $<0.05$ were considered statistically significant.

\section{Ethical Considerations}

Ethical clearance was obtained from the University of Gondar school of pharmacy's ethics review committee. Then, a support letter with this was offered to the Gondar town administration Health office, and we get permission from each Keble's administrative. Participation of all respondents should be voluntary, and we are ensuring informed written consent before engaging in the study. We are acquiring measures to assure the respect, norms, values, beliefs, culture, and freedom of each individual participating in the study. Information on the purpose and procedures of the study was explained; confidentiality will maintain by omitting their identifications such as names and assured a great deal of care and the information obtained is anonym to all study participants. 


\section{Result}

\section{socio-demographic characteristics of respondents}

A total of 215 community pharmacists were approached of which 95(44.2\%) were druggists, 200 (93\%) are private pharmacies, $149(69.3 \%)$ were in the age range of 26-35 years old. The majority of the respondents $118(44.9 \%)$ were female and $132(64.1 \%)$ where their educational level is the diploma. The majority of the respondents $137(61.4 \%)$ had 0 to 5 years of experience, 153(71.2\%) had those working < 8 hours per day, 159(74\%) had not taken seminar/training on ADRs reporting. Respondents whose average or mean number of patients visit per day, and working hours were 9.20, and 2.29 respectively.

\section{(Table 1).}

Figure 1: Distribution of study participants by their pharmacy Type where they work, Gondar, Ethiopia, $2021(n=215)$

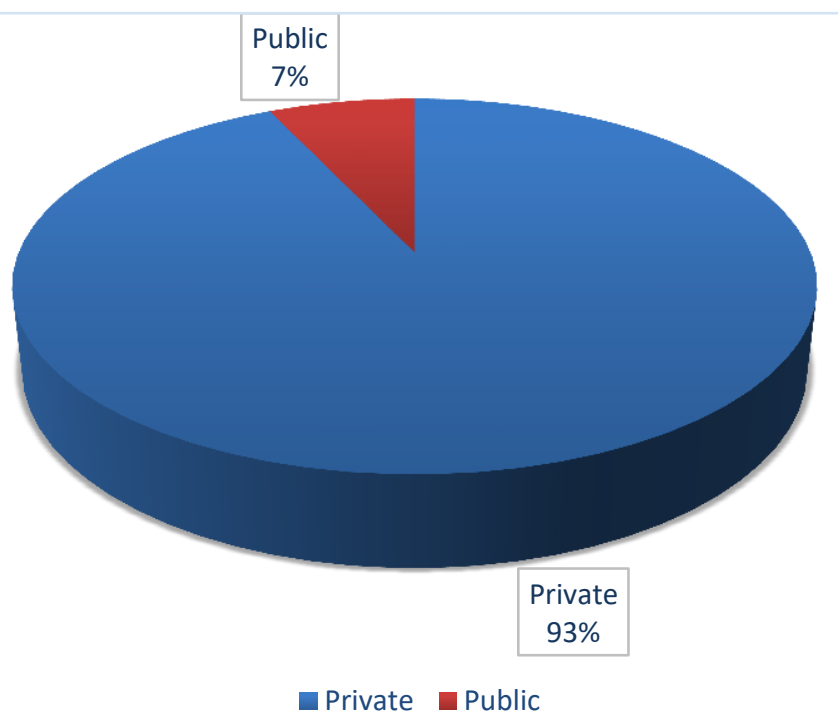


Table 1:Socio-demographic characteristics of pharmacy personnel working at community pharmacies of Gondar, Ethiopia, August $2021(\mathrm{n}=215)$

\begin{tabular}{|c|c|c|}
\hline Variables & Category & Frequency \\
\hline \multirow[t]{2}{*}{ Types of pharmacy } & Private & $200(93 \%)$ \\
\hline & Public & $15(7 \%)$ \\
\hline \multirow[t]{4}{*}{ Age } & $<25$ & $44(20.5 \%)$ \\
\hline & $26-35$ & $149(69.3 \%)$ \\
\hline & $36-45$ & $20(9.3 \%)$ \\
\hline & $>45$ & $2(0.9 \%)$ \\
\hline \multirow[t]{2}{*}{ Sex } & Male & $97(45.1 \%)$ \\
\hline & Female & $118(44.9 \%)$ \\
\hline \multirow[t]{4}{*}{ Professions } & Pharmacist & $83(38.6 \%)$ \\
\hline & Druggist & $95(44.2 \%)$ \\
\hline & Pharmacy technician & \\
\hline & & $37(17.2 \%)$ \\
\hline \multirow[t]{3}{*}{ Level of education } & Diploma & $132(64.1 \%)$ \\
\hline & Bachelor (Bpharm) & $82(38.1 \%)$ \\
\hline & Other & $1(0.5 \%)$ \\
\hline \multirow[b]{2}{*}{ Working hours per day } & $<8$ hours & $153(71.2 \%)$ \\
\hline & $>8$ hours & $62(28.8 \%)$ \\
\hline \multirow[t]{2}{*}{ Do you introduce ADR in your undergraduate study } & Yes & $154(71.6 \%)$ \\
\hline & No & $61(28.4 \%)$ \\
\hline \multirow[b]{2}{*}{ Do you get seminar/training on ADRs reporting } & Yes & $56(26 \%)$ \\
\hline & No & $159(74 \%)$ \\
\hline
\end{tabular}

\section{Knowledge of the respondents}

The overall knowledge score of the respondents, out of the 11 knowledge questions. 169, 78.6\% [95\% CI: 52.6-85.9] of the respondents and 21.4\% [95\% CI: 38.2-65.9] of the respondents had a good and poor knowledge level, respectively.

The majority of the respondents 34, (15.8\%) were able to differentiate ADR from side effects and only $88,(40.9 \%)$ respondents were knowing the definition of what ADR means. On the other hand, from 215 
respondents $78,(36.3 \%)$ knew the availability of a national reporting system and ADR reporting form in Ethiopia. Sixty-nine respondents (32.1\%) didn't know the correct format in which ADRs were to be reported. Similarly, 64, (29.8) respondents were that well documented at the time a drug is marketed ADRs, and a majority of respondents 135, (62.8\%) were respond that the reports for ADRs were supposed to be sent for EFDA.

The majority of respondents 189, (87.9\%), 140, (65\%),168, (78.1\%), and 158, (73.5\%) were answered pharmacy is required to report suspected cases of ADR, Conventional medicines vaccines, and blood products reactions should be reported, is primarily responsible to remind and follow up patients about side effects of drugs they are given for pharmacy technician, and monitoring ADR was the responsible for EFDA in Ethiopia respectively (Table 2).

Table 2:Knowledge of pharmacy personnel working at community pharmacies of Gondar, Ethiopia, August $2021(n=215)$

\begin{tabular}{|c|c|c|}
\hline Variables & categories & Frequency \\
\hline \multirow{2}{*}{$\begin{array}{l}\text { Do you think that an adverse drug reaction is the } \\
\text { same as a side effect? }\end{array}$} & Yes & $34(15.8 \%)$ \\
\hline & No & $181(84.2 \%)$ \\
\hline \multirow{2}{*}{$\begin{array}{l}\text { Do you know the term pharmacovigilance } \\
\text { (ADR)? }\end{array}$} & Yes & $88(40.9 \%)$ \\
\hline & No & $127(59.1 \%)$ \\
\hline \multirow{2}{*}{$\begin{array}{l}\text { Do you know the existence of a national ADR } \\
\text { reporting system? }\end{array}$} & Yes & $78(36.3 \%)$ \\
\hline & No & $137(63.7 \%)$ \\
\hline \multirow[t]{2}{*}{ Do you know the ADR reporting form? } & Yes & $146(67.9 \%)$ \\
\hline & No & $69(32.1 \%)$ \\
\hline \multirow{2}{*}{$\begin{array}{l}\text { Do you think that ADRs are well documented at } \\
\text { the time a drug is marketed? }\end{array}$} & Yes & $64(29.8 \%)$ \\
\hline & No & $15170.2 \%)$ \\
\hline \multirow{6}{*}{$\begin{array}{l}\text { Where are the reports for ADRs supposed to be } \\
\text { sent? }\end{array}$} & $\mathrm{MOH}$ & $24(11.2 \%)$ \\
\hline & FDA & $135(62.8 \%)$ \\
\hline & PFSA & $32(14.9 \%)$ \\
\hline & HENRI & $10(4.7 \%)$ \\
\hline & $\mathrm{EPA}$ & $6(2.8 \%)$ \\
\hline & All & $8(3.7 \%)$ \\
\hline \multirow{3}{*}{$\begin{array}{l}\text { Which profession is required to report suspected } \\
\text { cases of ADRs? }\end{array}$} & Doctors & $11(5.1 \%)$ \\
\hline & Pharmacy & $189(87.9 \%)$ \\
\hline & Nurses & $15(7.0)$ \\
\hline
\end{tabular}




\begin{tabular}{lll}
\hline What reactions should be reported? & Conventional medicines & $140(65 \%)$ \\
& vaccines and blood products & \\
& Herbal medicines & $32(14.9 \%)$ \\
& (traditional medicines) & \\
& cosmetics & $15(7 \%)$ \\
& Medical devices & $6(2.8 \%)$ \\
& others & $12(5.6 \%)$ \\
Who do you think is primarily responsible to & & $10(4.7 \%)$ \\
remind and follow up with patients about the side & Pharmacy Technicians & $168(78.1 \%)$ \\
& Pharmacy professionals & $31(14.4 \%)$ \\
& Physicians (Doctors) & $5(2.3 \%)$ \\
& Nurses & $3(1.4 \%)$ \\
& Other & $8(3.7 \%)$ \\
\hline Whom do you think is responsible for monitoring & MOH & $25(11.6 \%)$ \\
& FDA & $158(73.5 \%)$ \\
& EPA & $22(10.2 \%)$ \\
& UoG & $2(0.9 \%)$ \\
& Other & $8(3.7 \%)$ \\
\hline
\end{tabular}

\section{The attitude of the respondents}

The total attitude score of the respondents, out of the 10 attitude questions. 124, 57.7\% [95\% CI: 46.379.9], and 42.3\% [95\% CI: 38.5-68.2] of the respondents had a positive attitude and negative attitudes on Adverse drug reaction respectively.

The majority of respondents have been reported that 112, (52.1\%) strongly agree on Adverse Drug Reaction reported regularly,117, (54.4\%) strongly agreed Adverse Drug Reaction reported reporting is part of the duty of health professionals,116(54\%) were strongly agree on Reporting drug safety is important for the public.

On the other hand, 75(34.9\%) respondents were agreeing on there is no national Adverse Drug Reaction reported reporting system 117, (54.4\%) were agreed that Adverse Drug Reaction reported is a breach of patient confidentiality, 104(48.4\%) were agree on Reporting form is not available adequately, 78(36.3\%) were agree on Lack of motivation for reporting Adverse Drug Reaction reported, and 49(22.8\%) were Reporting creates additional workload for community pharmacy. (Table 3). 
Table 3:Attitudes of pharmacy personnel working at community pharmacies of Gondar, Ethiopia, August $2021(n=215)$

\begin{tabular}{|c|c|c|}
\hline Variables & Categories & Frequency \\
\hline \multirow{4}{*}{ ADR should be reported regularly } & Strongly agree & $112,(52.1 \%)$ \\
\hline & Agree & $93,(43.3 . \%)$ \\
\hline & Neutral & $4,(1.9 \%)$ \\
\hline & Disagree & $6,(2.8 \%)$ \\
\hline \multirow{4}{*}{$\begin{array}{l}\text { ADR reporting is part of the duty of health } \\
\text { professionals }\end{array}$} & Strongly agree & $117,(54.4 \%)$ \\
\hline & Agree & $83,(38.6 \%)$ \\
\hline & Neutral & $14,(6.5 \%)$ \\
\hline & Disagree & $1,(0.5 \%)$ \\
\hline \multirow{4}{*}{ Reporting drug safety is important for the public } & Strongly agree & $116,(54 \%)$ \\
\hline & Agree & $88,(40.9 \%)$ \\
\hline & Neutral & $8,(3.7 \%)$ \\
\hline & Disagree & $3,(1.4 \%)$ \\
\hline \multirow{4}{*}{ Reporting drug safety is important for the patient } & Strongly agree & $65,(30.2 \%)$ \\
\hline & Agree & $144,(67 \%)$ \\
\hline & $\begin{array}{l}\text { Neutral } \\
\text { Disaoree }\end{array}$ & $4,(1.9 \%)$ \\
\hline & Strongly disagree & $2,(0.9 \%)$ \\
\hline \multirow{4}{*}{$\begin{array}{l}\text { Reporting drug safety is important for the health care } \\
\text { system }\end{array}$} & Strongly agree & $59,(27.4 \%)$ \\
\hline & Agree & $141,(65.6 \%)$ \\
\hline & Neutral & $11,(5.1 \%)$ \\
\hline & Disagree & $4,(1.9 \%)$ \\
\hline \multirow{4}{*}{$\begin{array}{l}\text { There is a need to be sure that an ADR is related to the } \\
\text { drug before reporting }\end{array}$} & Strongly agree & $41,(19.1 \%)$ \\
\hline & Agree & $127,(59.1 \%)$ \\
\hline & Neutral & $30,(14 \%)$ \\
\hline & Disagree & $17,(7.9 \%)$ \\
\hline \multirow{4}{*}{ Only ADRs of prescription drugs need to be reported } & Strongly agree & $14,(6.5 \%)$ \\
\hline & Agree & $96,(44.7 \%)$ \\
\hline & Neutral & $42,(19.5 \%)$ \\
\hline & Disagree & $40,(18.6 \%)$ \\
\hline
\end{tabular}




\begin{tabular}{|c|c|c|}
\hline & Strongly disagree & $23,(10.7 \%)$ \\
\hline \multirow{5}{*}{$\begin{array}{l}\text { Only ADRs that cause persistent disability } \\
\text { or incapacity should be reported }\end{array}$} & Strongly agree & $9,(4.2 \%)$ \\
\hline & Agree & $98,(45.6 \%)$ \\
\hline & Neutral & $39,(18.1 \%)$ \\
\hline & Disagree & $48,(22.3 \%)$ \\
\hline & Strongly disagree & $21,(9.8 \%)$ \\
\hline \multirow{5}{*}{ Reporting of ADR should be voluntary } & Strongly agree & $19,(8.8 \%)$ \\
\hline & Agree & $127,(59.1 \%)$ \\
\hline & Neutral & $36,(16.7 \%)$ \\
\hline & Disagree & $28,(13 \%)$ \\
\hline & Strongly disagree & $5,(2.3 \%)$ \\
\hline \multirow{5}{*}{$\begin{array}{l}\text { Community pharmacists can contribute to the detection } \\
\text { and reporting of ADRs }\end{array}$} & Strongly agree & $9,(4.2 \%)$ \\
\hline & Agree & $98,(45.6 \%)$ \\
\hline & Neutral & $39,(18.1 \%)$ \\
\hline & Disagree & $48,(22.3 \%)$ \\
\hline & Strongly disagree & $21,(9.8 \%)$ \\
\hline \multicolumn{3}{|c|}{ Reasons for not reporting ADR } \\
\hline \multirow{5}{*}{$\begin{array}{l}\text { Need to be certain of the association between the drug } \\
\text { and ADR }\end{array}$} & Strongly agree & $42,(19.5 \%)$ \\
\hline & Agree & $139,(64.7 \%)$ \\
\hline & Neutral & $20,(9.3 \%)$ \\
\hline & Disagree & $8,(3.7 \%)$ \\
\hline & Strongly disagree & $5,(2.3 \%)$ \\
\hline \multirow{5}{*}{ Reporting ADR is a breach of patient confidentiality } & Strongly agree & $31,(14.4 \%)$ \\
\hline & Agree & $117,(54.4 \%)$ \\
\hline & Neutral & $34,(15.8 \%)$ \\
\hline & Disagree & $27,(12.6 \%)$ \\
\hline & Strongly disagree & $6,(2.8 \%)$ \\
\hline \multirow{4}{*}{ One report makes no difference } & Strongly agree & $13,(6 \%)$ \\
\hline & Agree & $44,(20.5 \%)$ \\
\hline & Neutral & $55,(25.6 \%)$ \\
\hline & Disagree & $92,(42.8 \%)$ \\
\hline
\end{tabular}




\begin{tabular}{|c|c|c|}
\hline & Strongly disagree & $11,(5.1 \%)$ \\
\hline \multirow{5}{*}{ The reporting form is not available adequately } & Strongly agree & $17,(7.9 \%)$ \\
\hline & Agree & $104,(48.4 \%)$ \\
\hline & Neutral & $27,(12.6 \%)$ \\
\hline & Disagree & $42,(19.5 \%)$ \\
\hline & Strongly disagree & $25,(11.6 \%)$ \\
\hline \multirow{5}{*}{ There is no national ADR reporting system } & Strongly agree & $9,(4.2 \%)$ \\
\hline & Agree & $75,(34.9 \%)$ \\
\hline & Neutral & $42,(19.5 \%)$ \\
\hline & Disagree & $67,(31.2 \%)$ \\
\hline & Strongly disagree & $21,(9.8 \%)$ \\
\hline \multirow{5}{*}{ Reporting is not useful to the patient } & Strongly agree & $4,(1.9 \%)$ \\
\hline & Agree & $24,(11.2 \%)$ \\
\hline & Neutral & $19,(8.8 \%)$ \\
\hline & Disagree & $132,(61.4 \%)$ \\
\hline & Strongly disagree & $36,(16.7 \%)$ \\
\hline \multirow{5}{*}{ Reporting creates an additional workload } & Strongly agree & $14,(6.5 \%)$ \\
\hline & Agree & $49,(22.8 \%)$ \\
\hline & Neutral & $35,(16.3 \%)$ \\
\hline & Disagree & $101,(47 \%)$ \\
\hline & Strongly disagree & $16,(7.4 \%)$ \\
\hline \multirow{5}{*}{ Lack of motivation for reporting } & Strongly agree & $31,(14.4 \%)$ \\
\hline & Agree & $78,(36.3 \%)$ \\
\hline & Neutral & $25,(11.6 \%)$ \\
\hline & Disagree & $78,(36.3 \%)$ \\
\hline & Strongly disagree & $3,(1.4 \%)$ \\
\hline
\end{tabular}




\subsection{Practice of the respondents}

Concerning the attitudes of community pharmacy at Gondar town, Ethiopia about ADR reporting this study displayed patients with ADR that seen during the last 12 months were 115,(53.5\%), and patients seen with ADR during the last 12 months 86,(74.8\%) were ever reported the adverse drug reactions, majority of respondents 71,(78.1\%) were reported for Head of a pharmacy, and 95,(56.7\%) of community pharmacists in Gondar town usually advised their patients on possible adverse effects of drugs (Table 4).

Table 4:Attitude of pharmacy personnel working at community pharmacies of Gondar, Ethiopia, August $2021(n=215)$

\begin{tabular}{|c|c|c|}
\hline Variables & Categories & Frequency \\
\hline \multirow{2}{*}{$\begin{array}{l}\text { Have you ever encountered patients with ADRs in your } \\
\text { pharmacy practice, in the last } 12 \text { months? }\end{array}$} & Yes & $115,(53.5 \%)$ \\
\hline & No & $100,(46.5 \%)$ \\
\hline \multirow{5}{*}{$\begin{array}{l}\text { How many patients with ADR did you see during the last } 12 \\
\text { months? }\end{array}$} & One & $20,(17.4 \%)$ \\
\hline & Two & $65,(56.5 \%)$ \\
\hline & Three & $15,(13.0 \%)$ \\
\hline & Four & $10,(8.7 \%)$ \\
\hline & $>$ four & $5,(4.3 \%)$ \\
\hline \multirow[t]{2}{*}{ Have you ever reported adverse drug reactions? } & Yes & $86,(74.8 \%)$ \\
\hline & No & $29,(25.2 \%)$ \\
\hline \multirow{6}{*}{ To whom did you report? } & Head of & $71,(78.1 \%)$ \\
\hline & pharmacy & $4,(6.2 \%)$ \\
\hline & Manufacturers & $10,(7.4 \%)$ \\
\hline & EFDA & $4,(5.1 \%)$ \\
\hline & $\mathrm{MOH}$ & $26,(3.2 \%)$ \\
\hline & Others & \\
\hline \multirow{4}{*}{$\begin{array}{l}\text { How often do you advise your patients on possible adverse } \\
\text { effects of drugs you dispensed? }\end{array}$} & Usually & $95,(56.7 \%)$ \\
\hline & Sometimes & $17,(20.5 \%)$ \\
\hline & Rarely & $2,(12.5 \%)$ \\
\hline & Never & $1,(12.09 \%)$ \\
\hline
\end{tabular}




\section{Factors affecting reporting practice of Adverse Drug Reaction}

The result of the study showed that as age increases, the proportion of dispensers reporting ADR decreases i.e., $69.3 \%$ for the age group 20-25 years to $20.5 \%$ for the age group of 36 years and above; so, the logistic regression result showed that age was significantly associated with ADR reporting practice of the respondents. The percentage of diploma holder pharmacy professionals Pharmacy technicians (17.2\%) who practice ADR reporting was higher than those of degree holder pharmacy professionals (pharmacists) (39.6\%). Even though a high proportion of pharmacy personnel with having training on ADR reporting as compared to those with no training on ADR reporting it was found to have a significant association in the logistic regression (Table5).

Table 5:ADRs reporting Knowledge by Socio-demographic characteristics of respondents working at community pharmacies of Gondar own, Ethiopia.

\begin{tabular}{|c|c|c|c|c|}
\hline \multirow[t]{2}{*}{ Variables } & \multirow[t]{2}{*}{ Response } & \multicolumn{2}{|c|}{ ADR knowledge level } & \multirow[t]{2}{*}{ P value: } \\
\hline & & Good & Poor & \\
\hline \multirow[t]{2}{*}{ Sex } & Male & $53(24.6 \%)$ & $44(20.45 \%)$ & $0.032 *$ \\
\hline & Female & $21(9.7 \%)$ & $97(45.11)$ & \\
\hline \multirow[t]{3}{*}{ Professions } & Pharmacist & $72(33.48 \%)$ & $11(5.11 \%)$ & \\
\hline & Druggist & $52(24.18 \%)$ & $43(20 \%)$ & $0.000 *$ \\
\hline & Pharmacy technician & $26(12.09 \%)$ & $11(5.12 \%)$ & \\
\hline \multirow[t]{2}{*}{ Working Hours } & $<8$ hours & $61(28.37 \%)$ & $93(43.25 \%)$ & 0.460 \\
\hline & $>8$ hours & $46(21.4 \%)$ & $15(6.97 \%)$ & \\
\hline \multirow[t]{4}{*}{ Age } & $18-25$ & $12(5.58 \%)$ & $32(14.88 \%)$ & \\
\hline & $26-35$ & $92(42.79 \%)$ & $57(26.5 \%)$ & $0.015^{*}$ \\
\hline & $36-45$ & $8(3.72 \%)$ & $12(5.58 \%)$ & \\
\hline & $>45$ & $2(0.93 \%)$ & $0(0 \%)$ & \\
\hline \multirow{2}{*}{$\begin{array}{l}\text { Training on ADRs } \\
\text { reporting }\end{array}$} & Yes & $44(20.4 \%)$ & $12(5.58 \%)$ & $0.004^{*}$ \\
\hline & No & $65(30.2 \%)$ & $94(43.7 \%)$ & \\
\hline
\end{tabular}


Table 6:Determinants of ADRs reporting practice among pharmacy personnel working at community pharmacies of Gondar own, Ethiopia.

\begin{tabular}{|c|c|c|c|c|}
\hline \multirow[t]{2}{*}{ Variables } & \multirow[t]{2}{*}{ Response (n) } & \multicolumn{2}{|c|}{ ADR reporting practice } & \multirow[t]{2}{*}{$\operatorname{AOR}(95 \%, \mathrm{CI})$} \\
\hline & & Yes & No & \\
\hline \multirow[t]{4}{*}{ Professions } & Pharmacist $=83$ & $25(11.6 \%)$ & $58(26.9 \%)$ & 1 \\
\hline & Druggist $=95$ & $52(24.18 \%)$ & $43(20 \%)$ & ---------------- \\
\hline & Pharmacy & & & \\
\hline & technician=37 & $26(12.09 \%)$ & $11(.11 \%)$ & $*[\mathrm{OR}: 0.40349(.172 .948]$ \\
\hline \multirow[t]{4}{*}{ Age } & $18-25=44$ & $20(9.3 \%)$ & $24((11.16 \%)$ & 1 \\
\hline & $26-35=149$ & $121(56.3 \%)$ & $28(13.02 \%)$ & $*$ [OR:.421(.178-(.783 3.513] \\
\hline & $36-45=20$ & $14(6.5 \%)$ & $6(2.8 \%)$ & \\
\hline & $>45=2$ & $2(0.93 \%)$ & $0(0 \%)$ & \\
\hline \multirow{2}{*}{$\begin{array}{l}\text { Training on } \\
\text { ADRs reporting }\end{array}$} & Yes $=56$ & $43(20 \%)$ & $13(6.04 \%)$ & $*$ [OR: 0.29(0.352-3.889] \\
\hline & No $=159$ & $46(21.39 \%)$ & $113(52.5 \%)$ & 1 \\
\hline \multirow{5}{*}{$\begin{array}{l}\text { Responsible } \\
\text { bodies for } \\
\text { monitoring ADR } \\
\text { in Ethiopia }\end{array}$} & $\mathrm{MOH}=25$ & $12(5.5 \%)$ & $13(6.04 \%)$ & 1 \\
\hline & $\mathrm{EFDA}=158$ & $120(55.8 \%)$ & $38(17.6 \%)$ & \\
\hline & $\mathrm{PFSA}=22$ & $16(7.4 \%)$ & $8(3.7 \%)$ & \\
\hline & $\mathrm{UoG}=2$ & $1(0.46 \%)$ & $1(0.46 \%)$ & \\
\hline & Other $=8$ & $2(0.93 \%)$ & $6(2.79 \%)$ & $*[\mathrm{OR}: .421(.178-(.783-3.513]$ \\
\hline
\end{tabular}

$*_{p}<0.05$ considered as significant $p$-Value. 1 Reference 


\section{Discussion}

This study assessed the knowledge, attitudes, and practices of pharmacy personnel working at community pharmacies towards adverse drug reaction reporting. The finding of this study showed that only 56(26\%) of the participants had attended on job ADR monitoring and reporting pieces of training. This shows that the majority of pharmacy personnel working at community pharmacies have no proper training on ADR monitoring and reporting.

The study also showed that $181,(84.2 \%)$ of the respondents said that ADR is different from drug side effects. This figure is higher than the result reported for health care professionals in South West Ethiopia in which only $65.5 \%$ of the respondents said that ADR is not the same as a drug side effect(3). This difference may be because all of the participants in the present study were pharmacy professionals that are experts on drugs and the participants of the other study were not only pharmacy professionals. Only less than half of the respondents 78 , (36.3\%) knew the existence of a national ADR monitoring canter. This shows that the majority of the respondents have no information on the authority that monitors ADR in Ethiopia. This result is in line with a study that was conducted in Saudi Arabia in which $56 \%$ of the community pharmacists were unaware of the existence of the Saudi National Pharmacovigilance Center(2). The present study also showed that the educational level of diploma and above was found to be associated with a good knowledge score ( $\mathrm{p}$-value $=0.40349$. This may be because as a level of education increases the probability of encountering patients with ADR will increase and the dispensers will ask themselves or colleagues or other health professionals what to do with the reaction and will have information on ADR reporting as a result. This might be associated with the deficiency in addressing pharmacovigilance issues in the curriculum of the diploma program in addition to this, a majority (98.7\%) of the respondents who had taken on job ADR monitoring are pharmacists. In addition, taking on job ADR monitoring training was found to be significantly associated with good ADR reporting knowledge (P-value: 0.29). The importance of on job ADR monitoring and reporting training in promoting ADR reporting has been shown in studies in different countries. For example, the study in Saudi Arabia recommended that more knowledge about the importance of reporting ADRs through appropriate training courses should be encouraged to increase the role of community pharmacists in ensuring the use of safe medications by monitoring and reporting ADRs (2).

The findings of the present study also showed that $115,(53.5 \%)$ of the participants had encountered patients with ADR in the last 12 months; of whom $4.3 \%$ encountered four and above patients with ADRs. This shows that there is a high probability of encountering patients with ADRs in community pharmacies which would increase the ADR reporting rate if the pharmacy professionals are made aware 
of the importance of ADR reporting and equipped with the required knowledge on ADR reporting and materials needed for reporting.

A similar study in Ethiopia which assessed the knowledge, attitude, and practices of health care professionals working at hospitals on ADR monitoring and reporting showed that $56 \%$ of the participants had encountered patients with ADRs in the last 12 months(17). Another study which was done in selected public health facilities of South West Ethiopia showed that only $15.9 \%$ of the health care professionals involved in the study had encountered patients with ADRs(18). This shows that the probability of encountering patients with ADRs in community pharmacies could be either higher or equal to the probability of encountering patients with ADRs in public health facilities. This implies that the efforts that are made in public health facilities to promote ADR reporting should also be made at community pharmacies in order to increase ADR reporting rate and the pharmacy professionals in community pharmacies can play a great role in ADR monitoring and reporting.

Ethiopia in which none of the respondents that had encountered ADR reported the ADR to the responsible body (6) but it is different from the result of the Study done at public hospitals of Ethiopia. In this study, $5 \%$ of the respondents who reported they encountered ADR had submitted the reports to the responsible/relevant body that is EFDA(11). This might be because there were lots of efforts that are made at public health facilities especially hospitals to promote ADR reporting than what has been done for community pharmacies. Despite the poor knowledge among the respondents, the study showed that the majority $124(57.7 \%)$ of the dispensers had a positive attitude towards ADR reporting. The majority 117, (54.4\%), of the dispensers, strongly agreed that ADR reporting is part of the duty of health professionals. Reporting ADR is a breach of patient confidentiality, Reporting creates an additional workload and a lacks of motivation for reporting was also believed to be reasons for not reporting by $12.6 \%, 47 \%$ ), and $36.3 \%$ of the respondents, respectively. These reasons are found to be in common in the findings of the study conducted at public hospitals of Ethiopia (19). Assessment of ADR reporting practice determinants indicated that only being a druggist and pharmacy technician was a significant determinant of ADR reporting practice. According to the result of the logistic regression analysis druggist and pharmacy technicians were nearly three times more likely to report encountered ADRs than pharmacists. The other socio-demographic characteristics were not found to be significantly associated with the ADR reporting practice. Even though high proportions of pharmacists have good knowledge of ADR reporting than diploma holder pharmacy professionals, ADR reporting practice is better among diploma holder pharmacy professionals. This might implicate the presence of negligence or lack of motivation among the pharmacists to report ADRs. In addition, pharmacists 
might be busy with managerial activities in community pharmacies. These findings indicate the need for additional investigation on why pharmacists working at community pharmacies are not reporting ADRs as they had good ADR reporting knowledge than diploma holder pharmacy professionals.

\section{Conclusion}

Underreporting of ADR by community pharmacists was identified in this study. The majority of the respondents reported having identified ADR. But, only a few of them have ever reported to EFDA, which might partly be explained by lack of knowledge and misunderstandings about spontaneous reporting. The study strongly suggests that there is a great need to create awareness and to promote the reporting of ADR amongst community pharmacists.

Training sessions to simplify the role of various community pharmacists in ADR reporting will hopefully fill the observed gap in knowledge and practices.

\section{Competing interests}

The authors report no conflicts of interest

Funding: This research didn't receive any grants from any funding agency in the public, commercial, or not-for-profit sectors.

\section{Authors' contributions}

Libsuye Yalgaw Zimamu, Principal Investigator

Muluken Chanie Agimas and Dr. Gashaw Mehiret Wubet Technical Support in Data Collection and Analysis

\section{Acknowledgments}

First, I would like to express our gratitude to Deb tabor university, school of medicine and health science for providing this opportunity to develop a thesis report and allowing me to undertake my area of interest. 


\section{REFERENCES}

1. Ahmad A, Patel I, Balkrishnan R, Mohanta G, Manna P. An evaluation of knowledge, attitude and practice of Indian pharmacists towards adverse drug reaction reporting: A pilot study. Perspectives in clinical research. 2013;4(4):204.

2. Alsaleh FM, Alzaid SW, Abahussain EA, Bayoud T, Lemay J. Knowledge, attitude and practices of pharmacovigilance and adverse drug reaction reporting among pharmacists working in secondary and tertiary governmental hospitals in Kuwait. Saudi pharmaceutical journal. 2017;25(6):830-7.

3. Atsbeha BW, Suleyman SA. Medication knowledge, attitude and practice (kap) among University of Gondar freshman students, northwestern Ethiopia. Pharmacology online. 2008;1:4-12.

4. Ahmad A, Khan MU, Srikanth AB, Kumar B, Singh NK, Trivedi N, et al. Evaluation of knowledge, attitude and practice about self-medication among rural and urban north Indian population. International Journal of Pharmaceutical and Clinical Research. 2015;7(05):326-32.

5. Alaynesh G. Assessment of Knowledge, Attitude and Practices on Adverse Drug Reaction Reporting Among Pharmacy Personnel Working at Community Pharmacy, Addis Ababa, Ethiopia: Addis Ababa University; 2015.

6. Bogale AA, Amhara AF, Chang J, Bogale HA, Betaw ST, Gebrehiwot NT, et al. Knowledge, attitude, and practice of self-medication with antibiotics among community residents in Addis Ababa, Ethiopia. Expert review of anti-infective therapy. 2019;17(6):459-66.

7. Afifi S, Maharloui N, Peyman P, Namazi S, Gharaei AG, Jahani P, et al. Adverse drug reactions reporting: pharmacists' knowledge, attitude, and practice in Shiraz, Iran. International Journal of Risk \& Safety in Medicine. 2014;26(3):139-45.

8. Al Rabayah AA, Esra'a Mahmoud Hanoun RH, Rumman A. Assessing knowledge, attitude, and practices of health-care providers toward pharmacovigilance and adverse drug reaction reporting at a comprehensive cancer center in Jordan. Perspectives in clinical research. 2019;10(3):115.

9. Asmelashe Gelayee D, Binega Mekonnen G, Asrade Atnafe S, Birarra MK, Asrie AB. Herbal medicines: personal use, knowledge, attitude, dispensing practice, and the barriers among community pharmacists in Gondar, Northwest Ethiopia. Evidence-Based Complementary and Alternative Medicine. 2017;2017.

10. Adisa R, Omitogun TI. Awareness, knowledge, attitude, and practice of adverse drug reaction reporting among health workers and patients in selected primary healthcare centers in Ibadan, southwestern Nigeria. BMC health services research. 2019;19(1):1-14. 
11. Kassa Alemu B, Biru TT. Health cares professionals' knowledge, attitude, and practice towards adverse drug reaction reporting and associated factors at selected public hospitals in Northeast Ethiopia: a cross-sectional study. BioMed research international. 2019;2019.

12. Bilal AI, Tilahun Z, Osman ED, Mulugeta A, Shekabdulahi M, Berhe DF. Cosmetics use-related adverse events and determinants among Jigjiga town residents, Eastern Ethiopia. Dermatology and therapy. 2017;7(1):143-53.

13. Getachew M, Tewelde T. Cosmetic use and its adverse events among female employees of Jimma University, southwest Ethiopia. Ethiopian Journal of health sciences. 2018;28(6).

14. Mehra R, Mohanty V, Aswini YB, Kapoor S, Gupta V. Prevalence, patterns and sociocultural factors associated with the use of tobacco-based dentifrices (Gul) in India. Indian $\mathrm{J}$ Cancer. 2020;57(3):311-20.

15. Mwambete KD, Shemsika T. Prevalence of lifestyle drugs usage and perceived effects among university students in Dar es Salaam. Am J Biomed Res. 2014;2(2):29-35.

16. Rusmadi SZ, Syed Ismail SN, Praveena SM. Preliminary study on the skin lightening practice and health symptoms among female students in Malaysia. Journal of environmental and public health. $2015 ; 2015$.

17. Gidey K, Seifu M, Hailu BY, Asgedom SW, Niriayo YL. Healthcare professionals knowledge, attitude and practice of adverse drug reactions reporting in Ethiopia: a cross-sectional study. BMJ Open. 2020;10(2):e034553.

18. Shanko H, Abdela J. Knowledge, attitudes, and practices of health care professionals toward adverse drug reaction reporting in Hiwot Fana Specialized University Hospital, Harar, Eastern Ethiopia: a cross-sectional study. Hospital Pharmacy. 2018;53(3):177-87.

19. Hailu AD, Mohammed SA. Adverse drug reaction reporting in Ethiopia: a systematic review. BioMed Research International. 2020;2020. 
ANNEXES

Socio-Demographic characteristics

\begin{tabular}{|c|c|c|}
\hline $\mathbf{S} / \mathbf{N}$ & Variables & Values \\
\hline 1 & Type of the community pharmacy & $\begin{array}{l}\text { 1. Private } \\
\text { 2. Public }\end{array}$ \\
\hline 2 & Sex & $\begin{array}{l}\text { 1. Male } \\
\text { 2. female }\end{array}$ \\
\hline 3 & Age & ---------------(in years) \\
\hline 4 & Professions & $\begin{array}{ll}\text { 1. } & \text { Pharmacist } \\
\text { 2. } & \text { Druggist } \\
\text { 3. } & \text { Pharmacy technician } \\
\text { 4. } & \text { Other specify---------- }\end{array}$ \\
\hline 5 & Highest level of Education & $\begin{array}{ll}\text { 1. Diploma } \\
\text { 2. Bachelor } \\
\text { 3. } \\
\text { Other(mention)--------- }\end{array}$ \\
\hline 6 & Year of experience in drug dispensing & ----------(in years) \\
\hline 7 & $\begin{array}{l}\text { How many minutes do you take to attend to a } \\
\text { patient? }\end{array}$ & ---------------- (minutes) \\
\hline 8 & $\begin{array}{l}\text { What is the average number of patients that you } \\
\text { encounter per day? }\end{array}$ & --------------(Patients) \\
\hline 9 & $\begin{array}{l}\text { How many working hours per day do you spend in a } \\
\text { pharmacy? }\end{array}$ & 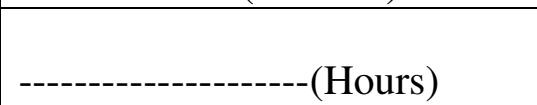 \\
\hline 10 & $\begin{array}{l}\text { Have you been introduced to ADR monitoring or } \\
\text { pharmacovigilance in your undergraduate study? }\end{array}$ & $\begin{array}{l}\text { Yes } \\
\text { No }\end{array}$ \\
\hline 11 & $\begin{array}{l}\text { Have you ever participated in any seminar/training } \\
\text { which includes a topic on ADRs reporting? }\end{array}$ & $\begin{array}{l}\text { Yes } \\
\text { No }\end{array}$ \\
\hline
\end{tabular}

Knowledge on ADRs Reporting

\begin{tabular}{|c|c|c|}
\hline $\mathbf{S} / \mathbf{N}$ & Variables & value \\
\hline 1 & $\begin{array}{l}\text { Do you think that an adverse drug reaction is the } \\
\text { same as a side effect? }\end{array}$ & 1. Yes, 2. No \\
\hline 2 & Do you know the term pharmacovigilance? & 1. Yes, 2. No \\
\hline 3 & $\begin{array}{l}\text { Do you know the existence of a national ADR } \\
\text { reporting system? }\end{array}$ & 1. Yes, 2. No \\
\hline 4 & Do you know the ADR reporting form? & 1. Yes, 2. No \\
\hline 5 & $\begin{array}{l}\text { Do you think that ADRs are well documented at } \\
\text { the time a drug is marketed? }\end{array}$ & 1. Yes, 2. No \\
\hline 6 & $\begin{array}{l}\text { Where are the reports for ADRs supposed to be } \\
\text { sent? }\end{array}$ & $\begin{array}{ll}\text { 1. MOH } & \text { 2. EFDA } \\
\text { 3. PFSA } & \text { 4. EHNRI }\end{array}$ \\
\hline
\end{tabular}




\begin{tabular}{|c|c|c|}
\hline & & 5. EPA $\quad$ 6.Other(mention) \\
\hline 7 & $\begin{array}{l}\text { Which profession is required to report suspected } \\
\text { cases of ADRs? }\end{array}$ & $\begin{array}{l}\text { 1) Doctors } \\
\text { 2) Pharmacy profession } \\
\text { 3) Nurses } \\
\text { 4) Traditional medicine practitioners } \\
\text { 5) Others mention -------- }\end{array}$ \\
\hline 8 & What reactions should be reported? & $\begin{array}{l}\text { 1. Those due to conventional } \\
\text { medicines } \\
\text { 2. Those due to vaccines and blood } \\
\text { products, } \\
\text { 3. Those due to herbal medicines } \\
\text { including traditional medicines } \\
\text { 4. Those due to cosmetics } \\
\text { 5. Those due to medical devices }\end{array}$ \\
\hline 9 & $\begin{array}{l}\text { Who do you think is primarily responsible to } \\
\text { remind and follow up with patients about the side } \\
\text { effects of drugs they are given? }\end{array}$ & $\begin{array}{l}\text { 1) Pharmacy professionals } \\
\text { 2) Physicians } \\
\text { 3) Nurses } \\
\text { 4) Other, specify--------------- }\end{array}$ \\
\hline 10 & $\begin{array}{l}\text { Who do you think is responsible for monitoring } \\
\text { ADR in Ethiopia? }\end{array}$ & $\begin{array}{ll}\text { 1) } & \text { MOH } \\
\text { 2) } & \text { EFDA } \\
\text { 3) } & \text { EPA } \\
\text { 4) } & \text { UoG } \\
\text { 5) } & \text { Other, specify---------------- }\end{array}$ \\
\hline
\end{tabular}

\section{Attitudes on ADRs reporting}

In the following table, please respond to the statements on your left-hand side by putting a tick () on the correct response on your right side

\begin{tabular}{|l|l|l|l|l|l|l|}
\hline & Statement & $\begin{array}{l}\text { Strongly } \\
\text { agree }\end{array}$ & Agree & $\begin{array}{l}\text { Neither } \\
\text { agree nor } \\
\text { disagree }\end{array}$ & Disagree & $\begin{array}{l}\text { Strongly } \\
\text { disagree }\end{array}$ \\
\hline 1 & ADR should be reported regularly & & & & & \\
\hline 2 & $\begin{array}{l}\text { ADR reporting is part of the duty } \\
\text { of health professionals }\end{array}$ & & & & & \\
\hline 3 & $\begin{array}{l}\text { Reporting drug safety is important } \\
\text { for the public }\end{array}$ & & & & & \\
\hline 4 & $\begin{array}{l}\text { Reporting drug safety is important } \\
\text { for the patient }\end{array}$ & & & & & \\
\hline 5 & $\begin{array}{l}\text { Reporting drug safety is important } \\
\text { for the health care system }\end{array}$ & & & & & \\
\hline
\end{tabular}




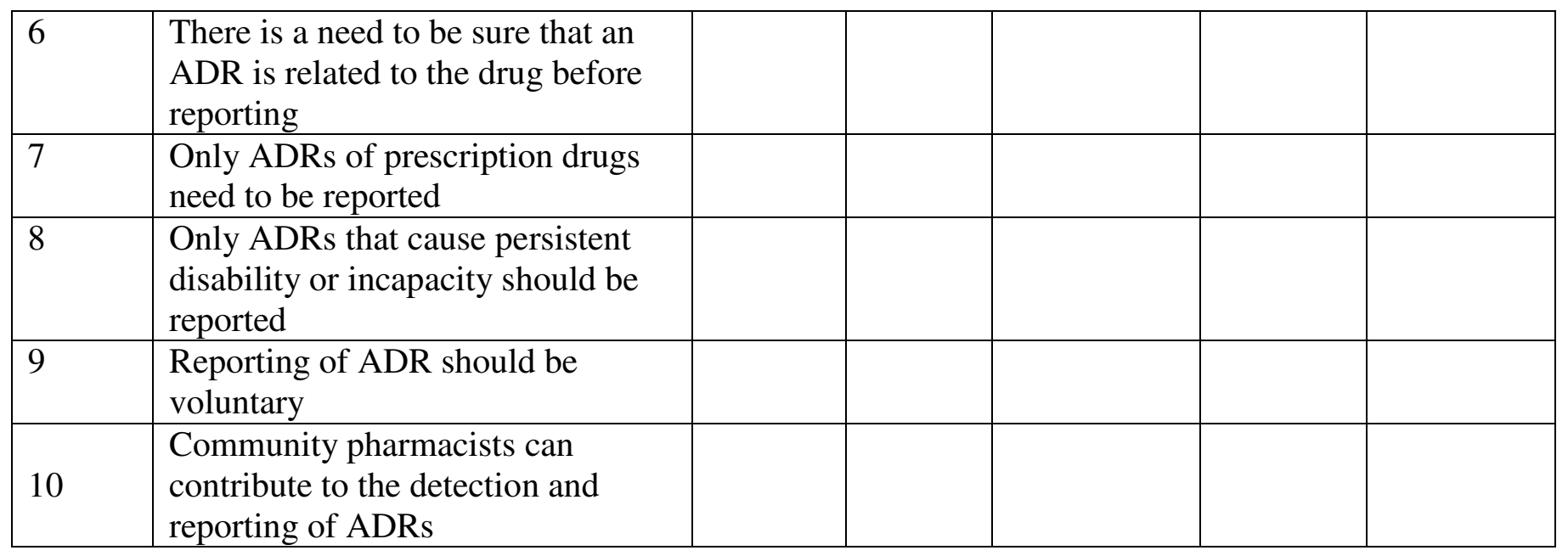

\begin{tabular}{|l|l|l|l|l|l|l|}
\hline & Reasons for not reporting ADR & $\begin{array}{l}\text { Strongly } \\
\text { agree }\end{array}$ & Agree & $\begin{array}{l}\text { Neither agree } \\
\text { nor disagree }\end{array}$ & Disagree & $\begin{array}{l}\text { Strongly } \\
\text { disagree }\end{array}$ \\
\hline 11 & $\begin{array}{l}\text { Need to be certain of the association } \\
\text { between the drug and ADR }\end{array}$ & & & & \\
\hline 12 & $\begin{array}{l}\text { Reporting ADR is a breach of patient } \\
\text { confidentiality }\end{array}$ & & & & & \\
\hline 13 & One report makes no difference & & & & & \\
\hline 14 & $\begin{array}{l}\text { The reporting form is not available } \\
\text { adequately }\end{array}$ & & & & & \\
\hline 15 & $\begin{array}{l}\text { There is no national ADR reporting } \\
\text { system }\end{array}$ & & & & & \\
\hline 16 & Reporting is not useful to the patient & & & & & \\
\hline 17 & $\begin{array}{l}\text { Reporting creates an additional } \\
\text { workload }\end{array}$ & & & & & \\
\hline 18 & Lack of motivation for reporting & & & & & \\
\hline
\end{tabular}

\section{Practices on ADRs reporting}

\begin{tabular}{|l|l|l|}
\hline S/N & Variables & Values \\
\hline $\mathbf{1}$ & Have you ever encountered patients with ADRs in & 1) Yes \\
& your pharmacy practice, in the last 12 months? \\
\hline $\mathbf{2}$ & How many patients with ADR did you see during the & 1) One \\
& 2) Two \\
& & 3) Three \\
\hline $\mathbf{3}$ & & 4) Four \\
\hline
\end{tabular}




\begin{tabular}{|l|l|l|}
\hline & Have you ever reported adverse drug reactions? & 2. No \\
\hline $\mathbf{4}$ & \multirow{3}{*}{ To whom did you report? } & 1) The head of the pharmacy \\
& & 2) Manufacturers \\
& & 3) FDA \\
& & 4) MOH \\
\hline $\mathbf{5}$ & 5) Others, specify ------ \\
& How often do you advise your patients on possible & 1) Usually \\
& adverse effects of drugs you dispensed? & 2) Sometimes \\
& & 3) Rarely \\
\hline
\end{tabular}

THANK YOU VERY MUCH FOR YOUR ATTENTION!!! 